\title{
Reminder and Online Booking Features at Android Based Motorcycle Repair Shop Marketplace
}

\author{
Wayan Dony Mahendra ${ }^{1}$, I Made Sukarsa ${ }^{2}$, AA.Kt.Agung Cahyawan ${ }^{3}$ \\ ${ }^{1,2,3}$ Department of Information Technology, Faculty of Engineering Udayana \\ University, Indonesia \\ Email: 1donymahendra31@gmail.com, ${ }^{2}$ sukarsa@ee.unud.ac.id, ${ }^{3}$ agung.cahyawan@unud.ac.id
}

\begin{abstract}
Generally, vehicle service is a must for the vehicle owner. However, due to tight work routines, people often forget to service their vehicles. Besides, the service process is still using a manual system, such as taking a queue number which leads to the long queue of the service time. An Android-based Motorcycle Repair Shop Information System provides a solution to remind people to do regular service on their vehicles with a reminder feature and make online bookings. The system development uses the SDLC (System Development Life Cycle) method. The implementation process requires an Android smartphone and a computer device by using MySQL as data storage, Firebase as a notification sender, React native, and Visual Studio Code are used for developing the system. The results of the UAT test (user acceptance testing) from 20 users show $55.8 \%$ answered agree to the display, features, and flow of the system, $39.5 \%$ answered strongly agree to the three question parameters, and $4.7 \%$ answered disagree with the flow and display of the system.
\end{abstract}

Keywords: Information Systems, Reminders, Online Booking, Motorcycle Repair Shop, Android

\section{INTRODUCTION}

Indonesian people have a tight routine activity in their work and daily lives. They mostly use a motorcycle as their vehicles in their daily activities or going to work. The reason people choose motorcycles than cars is due to the heavy traffic that postpones them from getting to their destination. Along with the busy routine activities and work, most motorcycle riders often forget to do service for their vehicles which should be done routinely. They also complained about the long service queue time that makes them ignore the time for vehicle service. The factors that cause this problem are due to time constraints that disrupt work time. In addition, forgetting the schedule of vehicle service is another factor that often happened by motorcycle riders in general.

Various research and solutions related to online reminders and bookings have been done by Patil Apurva A., Patil Gautami R., Patil Mansi S., Patil Renuka H. It explains the application to solve the problem for a long time waiting in the restaurant. The application will display information about various restaurants that

are nearby or far. This application will track the user's current location by using GPS and provide a list of the closest restaurants from their current location [1].

Other studies on Android-based applications is conducted by Deepti Ameta, Kalpana Mudaliar, and Palak Patel. It implements an automatic alarm system for the patients, 
therefore they do not need to recall the time to take their medicines and they can set an alarm at the dose timing. The alarm can be set for several medicine and time settings, including date, time, and description of the medicine [2]. A research conducted by I Gusti Made Satriya Wibawa develops an expired reminder system application with the Android platform. It is built and equipped with GIS (Geographic Information System) features to store and access locations that users need [3].

A research conducted by Mamay Syani, Nindi Werstantia explains an android-based catering ordering application that aims to help customers in the booking process of the catering without necessarily come to the location. This application is also developed for time and energy efficiency, as well as to get accurate information [4].

Research concerned with an Android-based Futsal Field Rental Application by Dwi Ratnasari, Hayatulloh Firman Hadi, and Jian Budiarto aims to help the booking process and down payment directly on the application [5]. The next research is conducted by Findra Kartika Sari Dewi, Theresia Devi Indriasari, Yoris Prayogo regarding an application of academic activity schedule reminders for lecturers and students. The application will provide a notification if there is a change in schedule on academic activities [6].

Kamaruddin Tone also conducted research about an android-based class reminder application that aims to remind students about exam schedules, lecture schedules, and assignment deadline schedules [7]. A research conducted by Ade Reza Pahlevi, Nur Ismawati, ST, M.Cs developed an android-based music application that aims to remind the preferred musician's gig schedule [8].

A research conducted by A research by Marlince N.K Nababan, Ricky Sandi Putra, Novi A.D Hutagaol discussed an Android-based hotel room booking application that aims to help the people in ordering and obtaining information about vacant hotel rooms [9]. Another research by Fani Panca Sari discussed an Android-based chef food ordering application that aims to help users in choosing a chef and food to be cooked as well as bring it home [10].

The next research is from Mr. Swapnil S. Nate, Mr. Pravin S. Navele, Mr. Vikas B. Mote, Prof. Laxman S. Naik which explains about the features which consist of three types of reminders namely basic reminders, schedule reminders and medication intake reminders, which will later work according to the schedule specified by the user. The main purpose of this application is to allow users to create reminders based on location and will later notify them automatically [11]. A research conducted by Prof. VB Dhore, Surabhi Thakar, Prajakta Kulkarni, Rasika Thorat aims to design and implement a food ordering system remotely, where customers can order food before visiting the restaurant, in addition, ordering tables and also payments [12].

Andy Fred Wali and Len Tiu Wright conducted research that can be used as a reference and support in implementing the reminder features and online booking features found in the Motorcycle Repair Shop application by learning how to apply CRM effectively 
to improve service quality in accordance with the research [13]. A research conducted by Susmitha Shree Lakshmi.S discusses an Android application that aims to establish communication between hospitals and patients. Customers can send requests to hospitals, therefore they can communicate by using the token number that has been given to the application. They also can find a list of hospitals that are nearby [14].

Based on research that has been done before, this study aims to design and build a motorcycle repair shop information system by applying the reminder and online booking features. The reminder feature aims to remind users who often forget to do service, while the online booking feature aims to make online booking services to reduce the length of vehicle service queues at a repair shop.

\section{METHODS}

The motorcycle repair shop information system uses the SDLC (System Development Life Cycle) waterfall model as system design. The SDLC method is a process for developing information systems consisting of 5 stages. The stages in the waterfall model are Analysis, Design, Implementation, Testing, and Maintenance. The stages of the research can be seen in Figure 1 [15].

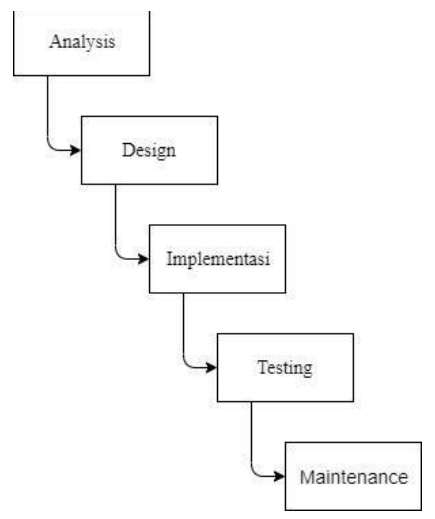

Figure 1. Research Stages

Figure 1 is the stage of system development by using the waterfall model SDLC (System Development Life Cycle) method. The analysis is the stage performed to determine the design of the application in order to answer all the needs needed by both parties, namely the repair shop and the customer. The second stage is a design or UI display of the repair shop information system that uses native-based as a layout in the design or display of the system. The third stage is the creation of a motorcycle repair shop information system. The implementation process requires an Android smartphone and computer devices by using Web Service, SQLYog, Firebase, Visual Studio Code, and React Native. The fourth stage is testing the developed system. It will be tested to find out the error contained in the system, and if there are many errors or malfunctions in it, a redesigning workflow will be performed to fix the system errors, therefore they can run as expected. The fifth stage is the maintenance of the system to keep the system running properly, improve the system, and the performance of the developed system. 


\section{RESULT AND DISCUSSION}

Results and discussion of Motorcycle Repair shop Information Systems include database design, context diagrams, and system testing.

\subsection{Database Design}

The database design in the Motorcycle Repair Shop Information System is depicted in the form of a PDM (Physical Data Model) diagram. The PDM design of the Motorcycle Repair Shop Information System as shown in Figure 2.

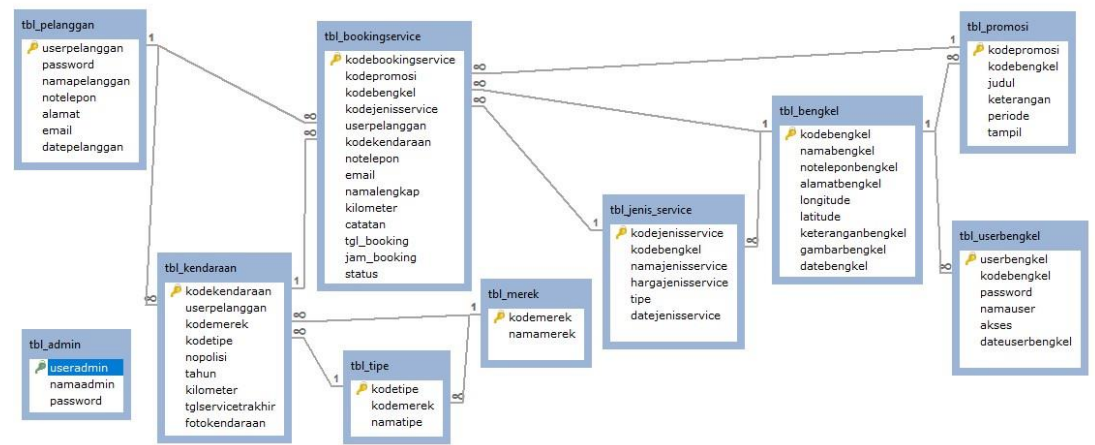

Figure 2. Physical Data Model of Motorcycle Repair Shop System

Figure 2 is a diagram of the Physical Data Model of the Motorcycle Repair Shop Information System. The PDM consists of 10 interconnected tables, tb_repairshopuser, tb_admin, tb_bookingservice, tb_type_service, tb_repairshop, tb_vehicle, tb_type, tb_brand, tb_promotion. The function of each Table will be explained in Table 1 .

Table 1. The function of the master Table on the motorcycle repair shop information system

\begin{tabular}{|c|c|c|}
\hline No & Table & Function \\
\hline 1 & Tbl_repairshop & Storing repair shop data \\
\hline 2 & Tbl_bookingservice & Storing booking service transaction data from customers \\
\hline 3 & $\begin{array}{l}\text { Tbl_ } \\
\text { repairshopuser }\end{array}$ & Storing data from the repair shop owner \\
\hline 4 & Tbl_customer & $\begin{array}{l}\text { Storing customer information to the repair shop, such as customer } \\
\text { users, passwords, etc. }\end{array}$ \\
\hline 5 & Tbl_vehicle & Storing vehicle data from customers \\
\hline 6 & Tbl_type_service & Storing services type data provided by the repair shop \\
\hline 7 & Tbl_promotion & Storing promotions from each repair shop \\
\hline
\end{tabular}

\subsection{Context Diagram}

The context diagram shows the whole process in the scope of the system. The scope of the Motorcycle Repair Shop Information System is presented with a context diagram. The context diagram will be explained in Figure 3. 


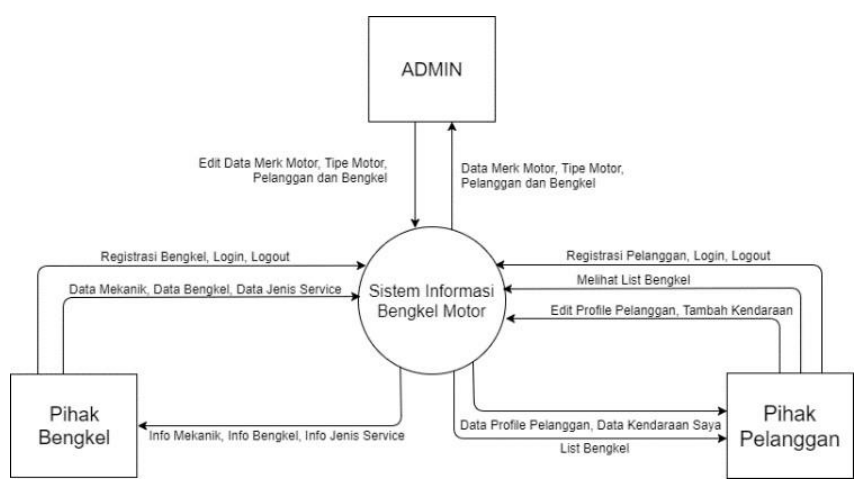

Figure 3. Context Diagram

Figure 3 is a context diagram of a Motorcycle Repair Shop Information System. The information system will be used by 3 actors, such as Repair shop, Customer and Admin. The repair shop can use the system to register, log in to the system, log out of the system, input their mechanical data, and manage their data and service type data. In addition, they also can obtain their mechanic information, repair shop information, and available service type information. The customer can use the system to register, $\log$ in to the system, log out of the system, view the repair shop list, manage their profiles, and add their vehicle information. In addition, they also can get customer profile information, customer vehicle data, and repair shop list. The admin can use the system to edit motorcycle brand and type data, also customer and repair shop data. In addition, they can use the system to obtain data in the form of motorcycle brand data, motorcycle type, and registered customer and repair shop data in the Motorcycle Repair Shop Information System.

\subsection{System Testing}

System testing of the Motorcycle Repair Shop Information System application includes direct system testing and the results of the UAT (User Acceptance Testing) test. The results of these two tests will be discussed as follows.

\subsubsection{Application Testing}

The Motorcycle Repair Shop Information System has two main features, namely the online booking feature for online booking service and the reminder feature to remind the users of their regular service. These features will be explained as follows.

\subsubsection{Booking Online Feature}

The customer can choose the repair shop and the time in the motorcycle repair shop application. A test to make online bookings is shown in Figure 4. 


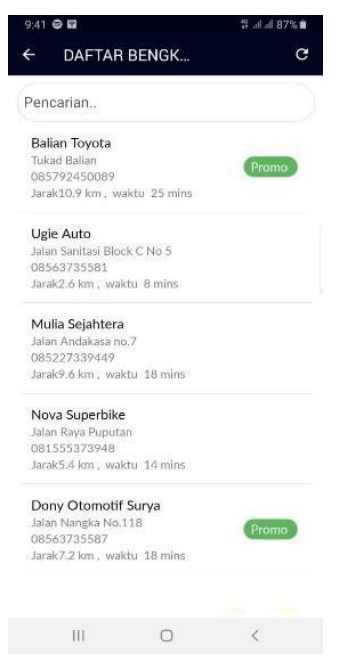

(a)

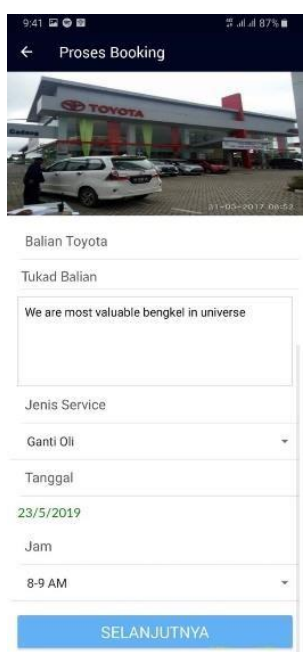

(b)

Figure 4. (a) Repair shop list (b) type of service and booking hours

The customer can choose the existing repair shop in the application as shown in Figure 4 (a) after choosing it, they choose the type of service to be performed on their vehicles and then choose the time that is available to make a booking as shown in Figure 4 (b). Confirmation of booking receipt from the repair shop will be displayed in Figure 5.
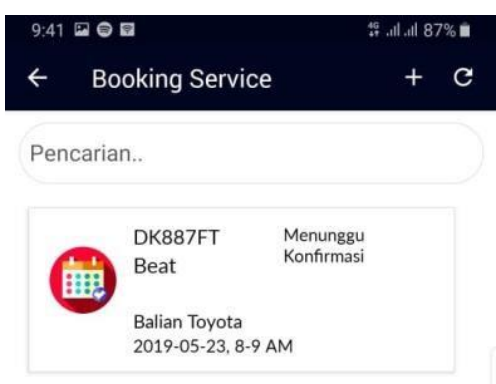

(a)

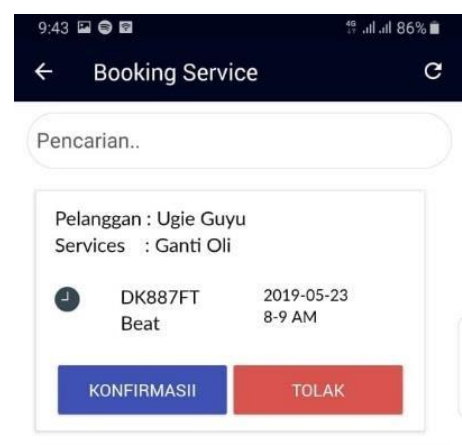

(b)

Figure 5. (a) Customer online booking (b) Repair Shop Booking Data

Figure 5 (a) explains that the customer will wait for confirmation from the workshop after filling in the data to make an online booking that has been shown in Figure 4 (b). the workshop can accept or reject bookings made by the customer as shown in Figure 5 (b).

\subsubsection{Reminder Feature}

The reminder feature is a feature on a motorcycle repair shop application that aims to remind users of doing regular service on motor vehicles. It will be displayed in Figure 6. 


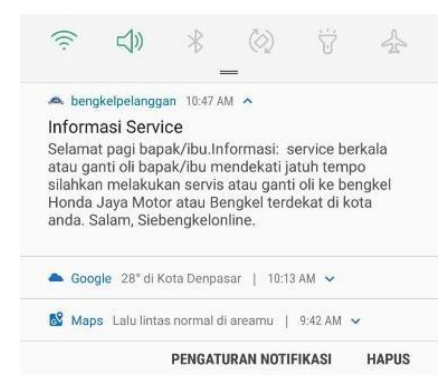

Figure 6. Reminder feature

Figure 6 is a notification display that will be received by the user within the specified time after making a booking service on the information system. The users will receive a notification after the first service is done and it is set by default by the repair shop which is in the next two months. The next reminder will be received by the user based on the average service time performed by that user.

\subsubsection{UAT (User Acceptance Testing)}

User Acceptance Testing is a stage of testing the system made in a number of questions to the user to find out the deficiencies of the development system. Question UAT (user acceptance testing) can be seen in Table 2 .

Table 2. UAT questions

\begin{tabular}{|c|c|c|c|c|c|}
\hline No & Question & SA & A & $\mathrm{D}$ & SD \\
\hline 1 & $\begin{array}{l}\text { Is the form on the application (login, registration, booking service, etc.) easy to } \\
\text { understand? }\end{array}$ & & & & \\
\hline 2 & Do the icons in the application present their functions and are easy to understand? & & & & \\
\hline 3 & Is the overall button layout in this application good? & & & & \\
\hline 4 & Is the information displayed on the application easier to understand? & & & & \\
\hline 5 & Is the color combination displayed on this application comforTable to see? & & & & \\
\hline 6 & Overall, is the display of this application good? & & & & \\
\hline 7 & $\begin{array}{l}\text { Does the Transaction History feature in the application describe your transaction } \\
\text { history? }\end{array}$ & & & & \\
\hline 8 & Can the Online Booking feature on the application help you with your service? & & & & \\
\hline 9 & Is the profile feature on the application able to describe yourself fully? & & & & \\
\hline 10 & Does the Reminder feature help you as a reminder of service time? & & & & \\
\hline 11 & Can the Deposit feature on the application help you make payments? & & & & \\
\hline 12 & $\begin{array}{l}\text { Is the My Vehicle feature in the application useful for you to find out the next } \\
\text { service time? }\end{array}$ & & & & \\
\hline 13 & $\begin{array}{l}\text { Does the process of creating a new account on this application have an easy and } \\
\text { fast process? }\end{array}$ & & & & \\
\hline 14 & $\begin{array}{l}\text { Does the process of booking service (with or without promotion) take a little time } \\
\text { and is not complicated? }\end{array}$ & & & & \\
\hline 15 & $\begin{array}{l}\text { Does the process for managing personal vehicle data (add, edit, delete) on the } \\
\text { application have a complicated process? }\end{array}$ & & & & \\
\hline 16 & Is the process for rating/reviewing workshops easy to do? & & & & \\
\hline 17 & $\begin{array}{l}\text { Does the process of adding a deposit balance to the application have an easy and } \\
\text { fast process? }\end{array}$ & & & & \\
\hline 18 & $\begin{array}{l}\text { Is the application able to run responsively and there are no system errors when } \\
\text { using the application (error, force closed, data not saved, etc.)? }\end{array}$ & & & & \\
\hline
\end{tabular}




\subsubsection{The result of UAT}

The result of UAT (user acceptance testing) is based on the result of application testing towards the customer (user). The test was distributed to 20 customers (users) with 18 questions divided into 3 parameters namely display, features, and system flow related to the Motorcycle Repair shop Application. The results showed 55.8\% answered agree to the display, features, system flow, $39.5 \%$ answered strongly agree to the threeparameter questions, and $4.7 \%$ answered disagree with the flow and display of the system.

Table 3. The result of UAT (user acceptance testing)

\begin{tabular}{lcccc}
\hline No & Stongly Agree (SA) & Agree (A) & Disagree (DS) & Strongly Disagree (SD) \\
\hline 1 & 9 & 11 & 0 & 0 \\
2 & 7 & 12 & 1 & 0 \\
3 & 6 & 12 & 2 & 0 \\
4 & 8 & 12 & 0 & 0 \\
5 & 6 & 13 & 1 & 0 \\
6 & 7 & 10 & 3 & 0 \\
7 & 5 & 14 & 1 & 0 \\
8 & 11 & 9 & 0 & 0 \\
9 & 8 & 11 & 1 & 0 \\
10 & 14 & 6 & 0 & 0 \\
11 & 7 & 11 & 2 & 0 \\
12 & 9 & 10 & 1 & 0 \\
13 & 6 & 14 & 0 & 0 \\
14 & 9 & 11 & 0 & 0 \\
15 & 7 & 13 & 0 & 0 \\
16 & 6 & 14 & 0 & 0 \\
17 & 9 & 8 & 3 & 0 \\
18 & 8 & 10 & 2 & 0 \\
\hline \multicolumn{2}{r}{ Total UAT Percentage: $39.5 \%$ Strongly Agree, 55.8\% Agree, $4.7 \%$ Disagree }
\end{tabular}

\section{CONCLUSION}

An Android-Based Motorcycle Repair Information System with 'reminder' and 'online booking' features are designed and applied in the form of a mobile application. The motorcycle repair shop application is designed as a medium to remind service time and reduce the length of service queues. The motorcycle repair shop information system is built specifically on mobile devices with the Android platform that can be used by customers (users). It was developed using the SDLC (System Development Life Cycle) method. The process of storing and processing data the system uses MySQL to support database services. The Android-based motorcycle repair shop information system with the 'reminder' feature utilizes Firebase as a media for sending reminder notifications to the application on Android mobile devices for customers and the system development uses React Native and Visual Studio Code. The result of UAT (user acceptance testing) from 20 users showed $55.8 \%$ answered agree to the display, features, system flow, $39.5 \%$ answered strongly agree to the three-parameter questions, and $4.7 \%$ answered disagree with the flow and display of the system.

\section{REFERENCES}

[1] Patil Apurva, A., Patil Gautami, R., Patil Mansi, S., \& Patil Renuka, H. (2017). Location based restaurant seat booking application for android phones: an 
overview. International Research Journal of Engineering and Technology (IRJET), 4(1), 1415-1418.

[2] Ameta, D., Mudaliar, K., \& Patel, P. (2015). Medication reminder and healthcare - an android application. International Journal of Managing Public Sector Information and Communication Technologies (IJMPICT), 6(2), 39-48.

[3] Made, I. G., Wibawa, S., Sukarsa, I. M., \& W, A. A. K. A. C. (2015). Aplikasi sistem reminder masa kadaluarsa berbasis GIS dengan platform android. Merpati, 3(1), 31-39.

[4] Syani, M. (2018). Perancangan aplikasi pemesanan catering berbasis mobile android. Jurnal Ilmiah Ilmu dan Teknologi Rekayasa, 1(2).

[5] Ratnasari, D., Hadi, H. F., \& Budiarto, J. (2018). Rancang bangun aplikasi penyewaan lapangan futsal berbasis android. JUTI: Jurnal Ilmiah Teknologi Informasi, 16(2), 144-157.

[6] Dewi, F. K. S., Indriasari, T. D., \& Prayogo, Y. (2016). Rancang bangun aplikasi pengingat kegiatan akademik berbasis mobile. Jurnal Buana Informatika, 7(4).

[7] Tone, K. (2018). Rancang bangun aplikasi class reminder berbasis android. Jurnal INSTEK (Informatika Sains dan Teknologi), 3(1), 161-170.

[8] Pahlevi, A. R. (2019). Analisa perancangan aplikasi musik dengan reminder event berbasis android. JUSIBI (Jurnal Sistem Informasi dan Bisnis Digital), $1(5)$.

[9] Hutagaol, N. A. D., Nababan, M. N., \& Putra, R. S. (2019). Aplikasi pemesanan kamar hotel berbasis android. Jurnal Sistem Informasi dan Ilmu Komputer Prima (JUSIKOM PRIMA), 2(2), 45-52.

[10] Sari, F. P. (2018). Aplikasi sistem informasi pemesanan koki dan masakan rumahan berbasis android. Jurnal SITECH: Sistem Informasi dan Teknologi, l(2), 123-126.

[11] Nate, S., Navele, P., Mote, V., \& Naik, L. (2016). Smart reminder application with GPS system. International Research Journal of Engineering and Technology, 3(4), 131-134.

[12] Dhore, V. B., Thakar, S., Kulkarni, P., \& Thorat, R. (2014). Digital table booking and food ordering system using android application. International Journal of Emerging Engineering Research and Technology, 2(7), 76-81.

[13] Wali, A. F., \& Wright, L. T. (2016). Customer relationship management and service quality: Influences in higher education. Journal of Customer Behaviour, 15(1), 67-79.

[14] S, S. S. L. (2016). Online Token Booking Application. International Journal of Engineering Trends and Technology (IJETT), 38(6), 297-301.

[15] Rani, S. B. A. S. U. (2017). A detailed study of software development life cycle (SDLC) models. International Journal Of Engineering And Computer Science, 6(7). 